\title{
SALES AND TITLE AND THE PROPOSED CODE
}

\author{
EIVIN R. LATTY*
}

Title, observed a well known writer on sales some years ago, "is still the fundamental factor in the law of sales." A reading of a group of judicial decisions dealing with sales, taken at random, would no doubt justify that observation. Did title ("the property") to the goods pass from the seller to the buyer at some point? That question traditionally has purported to solve a host of issues in the law of sales; if I may exaggerate for a moment, nearly everything in sales outside of "warranty" and a few other sales areas, seems to have turned on that question. In the law schools, the course in Sales often has amounted to a course on the rules of titlepassing. ${ }^{3}$ On the whole, the standard treatises have reflected this apparent stress on title and title-passing. This emphasis on a "pure" legal conception as a solvent of the work-a-day problems of the market is reminiscent of the former preeminence in corporation law of ultra vires, ${ }^{4}$ as well as of the concept of separate corporate entity, invisible, intangible, existing only in the eye of the law.

The traditional preoccupation with title-passing has not been without its counter currents. Particularly since the publication of Professor Llewellyn's casebook in 1930,5 the potency and adequacy of title-passing as a realistic solvent have been increasingly re-examined. A jurist of the stature of Learned Hand has observed in the course of a strong judicial opinion: "'title' is a formal word for a purely conceptual notion; I do not know what it means and I question whether anybody does, except perhaps legal historians." ${ }^{.6}$ Non-judicial legal literature increasingly refers to

- B.S. 1923, Bowdoin College; J.D. 1930, University of Michigan; J.Sc.D. 1936, Columbia University. Professor of Law, Duke University.

1 Waite, Book Review, 28 Mrch. L. Rev. 947,948 (1930).

"And even as to "warranty" in many states at common law title was (perhaps is) treated as of importance with respect to the remedy available to the buyer. Thus, in some states, in an executory contract of sale (where title had not passed), acceptance of the goods barred an action for damages for breach of certain warranties. Distinctions in application of the rule became rarified and conflicting. Again in some states, title-passing barred rescission for defective quality, in absence of other factors justifying rescission. The dilemma in which the combination of these rules could put the buyer is well analyzed in 3 Williston, SAles $\$ 489$ (Perm. ed. 1948). A notable achievement of the Uniform Sales Act was to curc these common law defects. UNIFORM SALEs Act $\$ \$ 49,69$.

${ }^{3}$ Of the two parts into which the contents of Williston \& McCurdy's Cases on Sales (r932 ed.) were divided, Part I, entitled "Transfer of Property and Title," embraced slightly over one-half of the book. Many instructors never get much beyond the first half of a casebook.

At one time, a treatise on the entire law of corporations could be published under the name of ultra vires; e.g., Seward W. Brice, A Treatise on the Doctrine of Ultra Vires (2d. Am. ed. i880).

EKari N. Lleweliy, Cases and Materials on the law of Sales (1930).

${ }^{\circ} \mathrm{L}$. Hand in In re Lake's Laundry, Inc., 79 F.2d 326, 328-329 (2d Cir. 1935). The court held, over L. Hand's dissent, that a title-reserving conditional seller of machinery could reclaim the chattels upon default despite the fact that the buyer corporation was in reorganization under $\$ 77 \mathrm{~B}$ of the Bankruptcy Act. Had the buyer purchased by giving back a purchase money mortgage as security, the 
the barrenness of title. Also, one hears that a highly critical attitude to title analysis is encountered in the halls of legal learning. ${ }^{7}$ However, to date few studies have been specifically devoted to the critical evaluation of the title-passing analysis in sales.

The title-analysis tradition, so strong at common law, persists with scarcely diminished vigor under the Uniform Sales Act which, like its model the English Sale of Goods Act, is largely a work of codification of common law attitudes. The persistence is abundantly demonstrated by the judicial decisions under both Acts.

Into this traditional juridical culture that is prone to "talk title" upon slight provocation, ventures the proposed Commercial Code ${ }^{8}$ with its deliberate belittling of title as a solvent of sales problems. The Comment to the opening section of the Sales Article of the Code expressly reveals that the purpose of the Article is to state legal consequences "as following directly from the contract and action taken under it without resorting to the idea of when property or title passed or was to pass as being the determining factor." 9 The Comment continues:

The purpose is to avoid making practical issues between practical men turn upon the location of an intangible something, the passing of which no man can prove by evidence and to substitute for such abstractions proof of words and actions of a tangible character.

Accordingly, the Code's approach is to come to grips directly with every issue (or, at least, nearly every significant issue) that traditionally has been solved, or sought to be solved, through the title concept. Thus the Code has sections specifically devoted to risk of loss, price actions, legal consequences of certain mercantile terms, and other phases later to be mentioned.

To illustrate the difference in approach between the Code, the Uniform Sales Act, and the common law (retarded or advanced), let us take a C \& F contract for r,000 drums of codfish from St. Johns, Newfoundland, to Philadelphia, price \$1o per roo-lb. drum, payment cash against documents (the documents to include, let us say, a negotiable bill of lading, seller's order, to be eventually presented duly endorsed); let us assume that the shipment is lost at sea in transit by casualty not covered by insurance; knowing this, the buyer refuses to pay when the documents are tendered; so the seller sues for the purchase price."10 The seller, we assume, lived

machinery would have "stayed in" the reorganization, as "property of the debtor," in the words of $\$ 77 \mathrm{~B}$ (b) (10). But here, because "title" was in the seller, the machinery could be pulled out. Such decisions lead one to wonder about the functional virtues of analysis in terms of title.

${ }^{7}$ Dean Prosser has stated to the writer that he had a standing rule when he was teaching the course in Sales: never was the student to "talk title" in discussing a case, at least if the ca'se involved the question of obligations and remedies between seller and buyer. Apparently Dean Prosser's notion was that if in such a case you can give no reason for a decision other than that title has or has not passed, you are not giving much of a reason.

${ }^{8}$ The "Sales" part of the proposed Code constitutes Article 2 of the Code, as set out in the May 1950 Proposed Final Draft. In the discussion that follows, references to the "Code" are to the Sales part (the Sales Article) of the Code and to the May $1950 \mathrm{draft}$, as modified by the September 1950 Revisions, unless otherwise indicated.

'CoDE, Comment to \$2-ror. By Article I of the Code, entitled "General Provisions," the courts are specifically invited to consult these official Comments as aids to determine the underlying reasons, purposes, and policies of the Code and as a guide, in its construction and application.

${ }_{10}$ The above facts are suggested by Smith Co. Ltd. v. Marano, 267 Pa. I07, r ro Atl. 94 (1920). 
up to all the contractual obligations resting upon him relating to the shipment of conforming goods. The issues thus presented are: is the seller entitled to recover his price, as distinguished from his right to some other recovery if indeed he has any right to recover at all; in turn, were the goods at buyer's risk or at seller's risk in transit? Under the Code, the analysis would run as follows:

I. By \$2-709, the seller is entitled to recover the price if conforming goods are lost "after risk of their loss has passed to the buyer." So we look to risk of loss.

2. By \$2-509, where the contract requires or authorizes the seller to ship the goods, "the risk of loss passes to the buyer when the goods are duly delivered to the carrier even though the shipment is under a bill of lading seller's order," unless the contract requires the seller to deliver at destination (in which event, risk of loss would pass "when the goods are there duly tendered"). So we look to see whether $\mathrm{C} \& \mathrm{~F}$ is a "destination contract."

3. By $\$ 2-320(3), a \mathrm{C} \& \mathrm{~F}$ contract imposes the same obligations and risks as a C.I.F. contract, except for the seller's obligation to obtain insurance for account of the buyer. So we look to the Code sections relating to C.I.F.

4. By $\$ 2-320(2)$, which sets out a list of shipment obligations imposed upon a seller under a C.I.F. contract, the inference is fairly clear that once the seller has properly done all those shipment things which he ought to have done, he is in the clear, and that a C.I.F. contract is not a contract whereby the seller undertakes to deliver at destination. This inference is further supported and clarified by the accompanying official Comment, which states that "the C.I.F. contract is not a destination but a shipment contract with the risk of subsequent loss or damage to the goods passing to the buyer upon shipment if the seller has properly performed all his obligations with respect to the goods."

The result of the foregoing analysis under the Code, then, is that the seller in the supposed case would be entitled to recover the purchase price. In all this analysis, be it noted, there is not a word about "title."

Under the present Uniform Sales Act, the analysis would be along the following lines. If title ${ }^{11}$ has passed to the buyer before the buyer's repudiation, the seller is entitled to recover the price, under $\$ \sigma_{3}(\mathrm{I}) .^{12}$ Or, following the thought that the seller is not entitled to recover the price if the goods were lost while they were still at his risk, one then looks to $\$ 22$ : under that section the goods "remain at the seller's risk" until title passes to the buyer (with exceptions not pertinent to the case under discussion). So, in any case, we look to see whether title has passed to the buyer. (Unlike the Code, the Uniform Sales Act has no sections specifically devoted to $C \& F$, either directed at specific legal aspects of $C \& F$ or to title-passing under

II To be technically accurate, it is the "transfer" of "the property" in the goods that entitles the seller to the price under Uniform Sales Act $\$ 6_{3}(I)$. "That Act speaks of the transfer of "the property" as between seller and buyer, but of the transfer of "title" as between the contracting parties and third persons. See the headings under Part II of the Act, preceding $\$ \S I 7$ and 23 . For the purpose of this paper, we shall use the term "passing of title" to cover both situations, a terminology of frequent use.

12 The other subsections of $\$ 6_{3}$, specifying other situations in which a price action is maintainable, would seem not pertinent to our hypothetical case. 
$\mathrm{C} \& \mathrm{~F}$.) We can readily dismiss any argument to the effect that the seller in our case still had title at the time of loss by retaining the bill of lading consigning the goods to seller's order; by $\$ \$ 20(2)$ and 22, the retention of such security does not prevent the passing of title or the risk of loss. So, the general title-passing sections of the present Act would come into play, particularly $\$ \$ 18$ and 19 . Section 18 is to the effect that title passes when the parties so intend, having regard to the terms of the contract, conduct of the parties, usages of trade, and circumstances of the case; while $\$ 19$ aims to help us discover the intention of the parties by laying down rules for ascertaining that intention, with the always-overriding qualification: "unless a different intention appears." Section Ig then lays down the rule (the closest to our case of the five rules under \$Ig) to the effect that if the seller is to pay the freight to destination, title does not pass till the goods arrive there. ${ }^{13}$ Now, by the very meaning of the "F" term in a $\mathrm{C} \& \mathrm{~F}$ contract, one of the things that the seller undertakes to do is to pay the freight to destination. (Although at this point one might get into an argument: does \$1o per drum C \& F Philadelphia mean that the seller prepays the freight to Philadelphia and the amount thereof is included in the \$ro price, or that the seller simply subtracts from his bill the amount of the freight which the buyer is to pay at the other end? Let us not belabor the point, except to say that the present Act is silent and that mercantile understanding seems to be that the seller prepays freight.) $)^{14}$ It might seem, then, that under the present Act; title would not pass upon shipment under a $\mathrm{C} \& \mathrm{~F}$ contract and thus the seller would not recover the purchase price from the buyer in our hypothetical case. ${ }^{15}$ But had this been a C.I.F. contract, the seller probably would recover because, while the " $F$ " term in C.I.F. points to title not passing, the " $\mathrm{I}$ " term points to title passing, and when you put them both on the scales, the "I" term is said to outweigh the "F" term, thereby providing that "different intention" to which the rules in $\$ x 9$ always give way. ${ }^{10}$ But the businessman will say that this difference in legal consequence between $\mathrm{C} \& \mathrm{~F}$ and C.IF. is absurd; that it is even more absurd to make this vital difference in legal consequences turn on imputing to the businessman thoughts about something he had no thoughts upon or intention of thinking about, viz., "title"; that C \& F is understood to be just like C.I.F. except that in C \& F the seller does not obligate himself to attend to insurance details. Perhaps the court will sym-

${ }^{13}$ Unifora Sales Act $\$ 19$, Rule 5: "If the contract to sell requires the seller to deliver the goods to the buyer, or at a particular place, or to pay the freight or cost of transportation to the buyer, or to $a$ particular place, the property does not pass until the goods have been delivered to the buyer or reached the place agreed upon."

${ }^{14}$ See Revised American Foreign Trade Definitions (I94I) adopted by a joint committee representing the Chamber of Commerce of the United States, the National Council of American Importers, Inc. and the National Foreign Trade Council, Inc., reported in 2 Williston, SalES 135 (Perm. ed. 1948).

${ }^{15}$ See remarks in Pittsburgh Provision \& Packing Co. v. Cudahy Packing Co., 260 Pa. 135, 103 Atl. 548,549 (1918), to the effect that "C \& F Pittsburgh" (from Kansas City) means the same as "F,O.B. Pittsburgh" - which in turn presumably would mean, if we "talk title," that title would pass at destination under C \& F. In this case, the rights of the parties were fixed before the state had adopted the Uniform Sales Act, but there is nothing in the Act that would compel a change of judicial attitude.

${ }^{10}$ Smith \& Co. Ltd. v. Marano, 267 Pa. 107, r10 Atl. 94 (1920). 
pathize with him; $;^{17}$ if so, the court might seize an opening for allowing "usages of trade" regarding C \& $\mathrm{F}$.to establish a non-title-passing-intention of the parties; or conceivably the court might find itself inclined not to resist an argument that Rule 5 of \$Ig contemplates, and only applies to, terms dealing with delivery (e.g., "Delivery: to carrier at St. Johns freight prepaid to Philadelphia") and that $\mathrm{C} \& \mathrm{~F}$ in the price term makes Rule 5 inapplicable, hence title passed on shipment as in the "usual" case. 18 Or the court may find that the documents showed that insurance, in our hypothetical C \& F case, was to be effected by the buyer, hence that title was intended to be in him during transit. ${ }^{19}$ It is readily apparent that these title-locating diffculties make prediction hazardous, to say the least.

If the law applicable to our hypothetical case were that of a state that has not adopted the Uniform Sales Act, leaving us at common law, the analysis would, as under the Act, run in terms of locating title, with comparable difficulties in application of the common law rules for locating title. In such a common law jurisdiction there are additional doctrinal troubles. For instance, there is common law authority (and of not too ancient vintage) to the effect that the seller's retention for security purposes of a seller's order bill of lading keeps title in the seller even after shipment. ${ }^{20}$ Moreover, resort to trade usages to ascertain intention at common law runs into snags. 21

The foregoing discussion illustrates the basic difference between the attitude of the common law and Uniform Sales Act and that of the Code towards resort to title in order to resolve particular issues, such as risk of loss and recovery of price (and many others). Despite the Code's minimization of title as a working tool, the Code nevertheless contains a fairly elaborate section, \$2-40I, devoted to the "passing of title." Several observations may be made on this apparent concession to the title tradition. First, the section in question restates, the better to emphasize the point, that the various provisions of the Sales part of the Code àpply "irrespective of title to the goods." Since most of the legal issues, and certainly the most important ones, traditionally resolved through title are directly covered by specific Code provisions, the areas wherein title is of importance thus become greatly limited. Second, one of this section's basic provisions, viz., that "unless otherwise expressly agreed title passes to the buyer at the time and place at which the seller completes his performance with reference to the physical delivery of the goods," seeks to select an objectively manifested physical act as the title-passing point. This is to avoid resorting to the classical "presumed intention of the parties" about an intangible something that the parties generally never thought about, viz., "title." Third, the Code recognizes that there may be a legitimate sphere for the operation of "title," that the eternal question

\footnotetext{
${ }^{17}$ Cf. Clark, C. J., in Madeirense Do Brasil S/A v. Stulman-Enrick Lumber Co., I47 F.2d 399, 402 (2d Cir. 1945).

${ }_{18}$ As in Secor v. Charles H. Tompkins Co., 45 A.2d 117 (D. C. Mun. Ct. 1946).

${ }^{10}$ Madeirense Do Brasil S/A v. Stulman-Enrick Lumber Co., 147 F.2d 399 (2d Cir. I945).

${ }^{30}$ See cases cited in 2 Williston, SAles $\$ 305 \mathrm{n}$. I6 (Perm. ed. 1948).

${ }^{21}$ Barnard v. Kellogg, to Wall. 383 (U. S. 1870), is illustrative.
} 
of mine and thine will persist and that there may be existing situations or novel situations which are not covered by the Code and in which, out of sheer lack of any other legal tool, the courts may have to fall back on title as a solvent. Accordingly, \$2-40I's rules concerning title are a sort of residual catch-basin, applicable by its very terms only "insofar as situations are not covered by the other provisions of this Article."

Criticism has been made of the novel language of the title-passing section of the Code, as requiring litigation to establish its meaning in those situations, not specifically covered, where title can still be of importance; criticism has also been directed to the Code's elimination of presumed intention as determining the passing of title. ${ }^{22}$ However, as to any matter which really is a significant element in a deal in a practical sense (and not in the who-has-title sense) not only is the matter most likely to be specifically treated in the Code but also in all probability it is one where the intention, express or implied, of the parties on that point will be a significant segment of their contract and hence respected under the Code. It is only in the outer fringes that, under the Code, one has to fall back on title, and in those fringes the location of title either by express agreement of the parties or by mandatory rule irrespective of agreement would seem preferable to the presumed-intention approach. ${ }^{23}$ Few areas of law are more productive of litigation than the location of title under the presumed-intention approach; to this day, despite the decisions under the Uniform Sales Act, it usually takes a litigation to establish what was the titlepassing intention of the parties. Later comments in this article will illustrate this point.

\section{II}

By minimizing the consequences of title-passing in most situations and by abandoning the search for presumed intention about title-passing in the residual cases, as well as by disregarding any claim of title-intention in some of the residual cases, the Code does depart, as Williston has said, "from the long established tests for determining title and the consequences of title or the lack of it."24 And the

22 Williston, The Law of Sales in the Proposed Commercial Code, 63 HARv. L. Rev. 561, 569 (1950).

${ }^{23}$ Section 2-40r (3) of the Code, as it appeared in the May, r950 Draft to the effect that "where delivery is to be made without moving the goods, if the goods are at the time of contracting already identified and no documents are to be delivered, title passes at the time and place of contracting," has by the September, I950 Revision been qualified by the words "unless expressly agreed." WILLISToN, supra note 22 , at 570 , in criticizing the previous mandatory aspect of $\$ 2-40 \mathrm{r}(3)$ raises this point: if $S$ contracts to sell to $B$ an identified Buick car at the end of the season, delivery to be taken at $S_{s}$ garage where the car is, why can't title pass at some point after the making of the contract if $S$ and $B$ so intend? With all due respect, I suggest that this attitude seems to make too much of title as an end in itself, with too little concern about the narrow issue that may be involved. If the narrow issue involved in the particular situation is none of the issues specifically treated in the Code (including rights of purchasers from and creditors of either $S$ or $B$ ), the then Code rule of title-passing at the time of bargain, irrespective of the parties' intention seems easier to apply and fully adequate to do justice and still respect freedom of contract-unless one is convinced that this basic freedom should include freedom to contract about title in vacuo disembodied from specific content. It will be a rare case where parties will make a present deal concerning an existing identified Buick and yet express concern about future passing of title, over and above express terms about who gets what and when, and who bears the risk meanwhile.

24 Williston, supra note 22 , at 570 . 
learned author adds that this is the most objectionable and irreparable feature of the Sales part of the Code. ${ }^{25}$ This criticism would be particularly forceful if we could agree that the traditional title-passing analysis at common law or under the Uniform Sales Act is working well. That is: (a) if the operative facts in sales transactions that effect title-passing afforded a good basis of prediction, in the light of the existing rules concerning the role of intention and the ascertainment of unexpressed intention, that a court will hold title has or has not passed in specific cases; and (b) if the determination that title has or has not passed adequately performed the various functions that title location is traditionally expected to perform (i.e., automatically settle questions like risk of loss, recovery of price, reclamation in bankruptcy, maintenance of replevin, measure of damages, etc.), then the present situation would be working well and would need no drastic overhauling. At the most, the situation would call for adoption of the Uniform Sales Act in those states that have not yet adopted the Act, and perhaps some minor amendment of that Act.

On the surface the present title-analysis approach looks good. The rules of the Uniform Sales Act and their common law counterparts (with the varying degrees of conflict of authority that we have come to expect as natural) seem on the surface easy to grasp. True, we sometimes have misgivings about the reality of ascertaining the presumed intent of the parties about something that they didn't think about, but we are accustomed to similar "finding" of the intent of the legislature in statutes and of parties in contracts. Moreover, the judicial opinions on title-passing, in isolated cases, seem on the whole to "read well" and to come to a "good" result. It is when you begin to dig below the surface that you strike trouble and confusion; and the further you dig the greater the confusion; and while I cannot claim where you end when you "exhaust" the explorations, I venture that the more you explore the more you become willing to take either side on an alleged title-passing question in most cases. To pursue and present this thought fully would require extended space; in the few pages allowed me, I can only give illustrative examples.

In Glass v. Blazer Bros.," ${ }^{26}$ the written instrument of sale recited that "Blazer Brothers has this day sold to Alex. Glass their entire crop of growing flax ... to be delivered at his elevator in Freeman, not later than September 15, at one dollar per bushel. ..." The market price went to $\$ \mathrm{r} .40$ per bushel and the sellers, weak against temptation, refused to deliver to buyer Glass at his elevator; indeed, they were about to sell to others when buyer Glass brought this action of replevin-successfully. Title had passed, said the court. Now, by all the traditional rules of title-passing (as well by the common law under which this case was decided as by the specific rule of the Uniform Sales Act $\$ 19$ relating to contracts requiring a seller to deliver at a particular place) title ought not to have passed. That is, title-in-the-abstract ought not to have passed-sheer title in the heaven of pure conceptions undefiled by such

${ }^{26} \mathrm{Id}$. at $57 \mathrm{I}$.

${ }^{36} \mathrm{gr}$ Mo. App. 564 (1902). 
mundane considerations as whether it is better to let the buyer get this flax or get a judgment against the welching seller and satisfy the judgment as best he can. The court's technique in "finding" that title had passed is instructive. The court pointed to the words "has this day sold" as showing a then-and-there title-passing intention; in addition, it distinguished away those decisions where, said the court, there remained something to be done as a condition precedent to the transfer of title. Yet scores of judicial opinions either tell us that the words "has sold" as distinguished from "has agreed to sell," are not particularly determinative, or else ignore the phraseology (pointedly, I would say) when it leans away from the title-passing decision. ${ }^{27}$ As for the "condition precedent" rationale, it seems fairly clear that the court could as easily (indeed, more easily) have labelled delivery at the elevator a "condition precedent." If these very goods had been destroyed by casualty before delivery to the elevator, I venture that the court would have "found" that title had not passed. Is it, then, that title may have passed for one purpose, viz., buyer's replevin from welching seller, but not for some other purpose, viz., risk of loss or personal property tax? Which suggests: was the court led (or misled, some might say) to its title position by sheer logic and analysis of title-laden propositions or by keeping a sharp eye on the end result and manipulating title so as to conform? Passing of title lends itself readily to manipulation, for it involves "finding" an intention about something that laymen in business deals don't think about and hence don't express themselves about; and the typical situation presents factors which can be worked up into sign posts pointing in opposite directions.

If the court in Glass v. Blazer Bros. was impelled to its decision not by title abstractions (despite what it said) but by its balancing of the policies, pro and con, on the narrow issue whether the buyer under such circumstances should be permitted an action to get the goods as distinguished from an action for damages, then, it is submitted, the holding of that case can best be stated not in terms of some broad rule about title-passing but perhaps as follows: "When the goods that are the subject matter of the contract of sale have become identified, then the buyer (upon making and keeping open a tender for any unpaid balance of the purchase price) may recover those goods from the seller if the seller repudiates or threatens to repudiate." Such a statement probably comes closer to "the truth" of that case than some proposition about title-passing. The Code, then, in approaching specific legal consequences directly instead of working through title is not making a radical departure after all, realistically. Furthermore, such a statement (or the opposite statement, if a different policy choice is made by the court) ${ }^{28}$ is better attuned to the

${ }^{27}$ The classic case of Tarling v. Baxter, 6 Barn. \& C. 360 (K.B. 1827) is itself an example.

${ }^{28}$ One could reasonably take the position, I believe, that there is little ground for "feeling strongly" on the policy question involved in the Glass case. It is interesting to note that in the Proposed Final Draft No. 1 of the Sales chapter of the proposed Code (draft of April 27, 1944) there was a section (\$72) to the effect that where the goods have been identified "the buyer may on making and keeping good a tender of any unpaid portion of their price recover them if the seller becomes insolvent or repudiates or refuses to deliver." Later drafts have abandoned this provision. However, the vitality of that thought is still evident in the 1950 draft of the Code, $\$ 2-502$, to the effect that a buyer who has 
ends sought to be achieved by the title concept than is the use of that concept. Moreover, such a statement (or, again its opposite or some qualification of it) is less likely to lay the foundation for the development of conflicting rules and impenetrable entanglements of fine distinctions as decisions after decisions pile up; consider, for example, the doctrinal developments that are likely to take place in the court that has decided the Glass case if a subsequent case, almost identical on titleaffecting facts, presents the issue of, say, risk of loss or seller's suit for the purchase price. $^{29}$

Other decisions invite similar reflections. Thus, in Everedy Machine Co.v. Hazle Maid Bakers, ${ }^{30}$ arising under the Uniform Sales Act, the seller made a machine to fit buyer's specifications as per contract, which machine the seller was to ship when completed. When the machine was ready, seller inquired how buyer wanted it shipped, by motor truck or freight. (At this point, title analysis would seem to indicate that title has not passed, for seller has not shipped yet.) Buyer repudiated. Seller sued for purchase price, and recovered. That this specially made machine could not readily be resold for a reasonable price would seem to be sufficient ground for the decision; indeed the court mentioned that ground. But the court's main ground, apparently, was that title had passed; the court "found" the intention to be that title was to pass when construction was completed and the buyer was notified to that effect; that the matter of shipment was merely one of "subsequent arrangement." The confusion caused by such a title analysis and the invitation to future refinements to distinguish it away are readily apparent, particularly if such judicial analysis is made in a state that has announced the doctrine that when several grounds for a decision are announced, all are "the law."

In Hopkins v. Bronangh, ${ }^{31}$ the buyer contracted early in December to buy some $\$ 60,000$ of bonds of specific issues. Seller was to mail the bonds to buyer about December 23 or 24 , to a specific place. At the time the contract was made, seller did not even own or possess a good part of the bonds called for by the contract. On December 20, buyer sent a check in payment. By December 24, seller had obtained about $\$ 50,000$ of the bonds and put them in an envelope on which he wrote the buyer's name, preparatory to forwarding them. Before seller got around to forwarding the bonds, however, seller became bankrupt. The buyer sued to

paid part or all of the price of existing goods identified as the goods to which the contract refers may, on appropriate tender of the balance of the price, recover them from the seller "if the seller becomes insolvent within ten days after receipt of the first installment on their price ..." Also, the I950 draft contains this provision:

$\$ 2-716(3)$. "The buyer may replevy goods identified to the contract if after reasonable effort he is unable to effect cover for such goods or the circumstances reasonably indicate that such effort will be unavailing."

(Another provision of that same $\$ 2-716$ would grant specific performance "in other proper circumstances.") Here again, be it noted, recovery of the goods themselves under the Code does not turn on title.

${ }^{39}$ If in the Glass case the seller, despite his refusal to deliver at the elevator as agreed, had been suing for the purchase' price, presumably no court would say: since title had passed, the seller is entitled to recover the price; let the buyer, if aggrieved, counterclaim for the seller's refusal to make the delivery. ${ }^{30} 334$ Pa. 553, 6 A.2d 505 (1939).

32 281 Fed. 799 (gth Cir. Ig22). 
recover these bonds. The lower court held that title had not passed; the Circuit Court of Appeals held that title had passed and that the buyer could recover the bonds. Here again was a case where by the orthodox rules of title-passing, both at common law and under the Uniform Sales Act (in force here at the time), one would have predicted, most likely, that title had not passed. Or is it that when the buyer has paid in advance and the goods have become identified, then even if the seller has not yet done all those things he ought to have done, title has passed for the purpose of buyer's reclamation in bankruptcy but title has not passed for, say, the purpose of risk of loss? The trouble is, at common law and under the Uniform Sales Act, one can venture neither an affirmative nor a negative answer to that suggested question; no one can tell when the court will hew to the title rules, ruat caelum, and let the chips fall where they may on the specific issue involved. It may be observed that the actual decision in the Hopkins case is strikingly similar to Code $\$ 2-502.32$

The Hopkins case is reminiscent of Young v. Matthews: $:^{33}$ there Moxon, a brickmaker, was indebted to Northen, who was pressing; so Moxon agreed to sell Northen $x, 300,000$ bricks. Buyer Northen sent his agent to the brick field, apparently to look the bricks over; let the official report tell what happened:

Moxon's foreman ... pointed out three clamps from which he should make the delivery, of which one consisted of finished bricks, a second was still burning, and the third consisted of bricks which had been moulded but not burnt. Northen's agent then said, "Do I clearly understand that you are prepared, and will hold and deliver this said quantity of bricks?" and Moxon's foreman said, "yes." Subsequently . . . Moxon became bankrupt ... and Northen afterwards sold ... to the defendant, who removed them from the field.

In an action of trover brought by Moxon's bankruptcy assignees against the defendant, recovery was denied; from the foregoing facts the court "found" that the parties intended to pass title to the bricks then and there, despite that much had yet to be done to put the bricks in a deliverable state. Here again, the seller's bankruptcy administrator lost out in his claim to title where the buyer had paid for the goods, even though payment here was merely. by application to an antecedent debt. $^{34}$

An endless procession of cases could be added to those above, increasing our doubts about the efficacy of title and furnishing strong proof that the title approach

${ }^{32}$ Stspra note 28.

${ }^{83}$ L. R. 2 C. P. 127,128 (1866).

${ }^{34}$ Under our Bankruptcy Act, such a situation today would raise a question whether the debtor had received a fraudulent or voidable preference; and as between the seller's bankruptcy trustee and the purchaser from the creditor-buyer (as was the defendant in this case), it would raise the question whether the purchaser was a bona fide purchaser from the debtor's transferce for a present fair equivalent value. See $\$ \$ 60(b)$, $70(d)$ of Bankruptcy Act. CODE $\$ 2-402(2)$ expressly preserves the rights of creditors (and hence of the bankruptcy trustee, to the extent that he gets creditors' rights by the Bankruptcy Act) "wherc identification to the contract and delivery are made not in current coursc of trade but in satisfaction of or as security for a pre-existing claim for money, security or the like and are made under circumstances which apart from this Article would constitute the transaction a fraudulent or voidable prcference." 
creates a magnificent illusion of certainty, if we judge by judicial actions rather than by judicial words. The presumed-intention difficulty in these title cases is not comparable to "finding" the intention of the legislature in a statute or of parties to a contract about something that they did not think about on some particular point. With respect to a statute or a contract, the court's job is to say what the legislature or the contracting parties would have said on that point if they had thought about it; or, perhaps, the court's job is to fill in with what it believes to be fair on that point. In either case, there is some specific point to grapple with-something tangible, one may say. But it seems pointless to ask: what would buyer and seller have said about title if they had thought of it. It seems equally pointless to ask what would be fair to find as to title-intention. To ask what would the parties have intended, or what is fair, as to measure of damages, risk of loss, or some other specific point, however, makes sense. If resort to finding unintended title-intention cannot be wholly eliminated from the law of Sales, attempts to minimize the occasion for such resort are at least to be encouraged.

III

\section{Some Code Treatments of Spectfic Matters Traditionally Resolved} Through the Tithe Concept

In the remaining limited space allowed to this paper, I shall not purport to make an extended commentary on what would be the analysis under the Code of every situation in sales law that involves discussion of title-passing. That would mean writing a treatise on the law of sales and several volumes of Code commentaries. Also for brevity, I shall in the main forego extended quotation of Code provisions which are frequently long and involved and full of cross references, in the belief that any one sufficiently interested to read this article will have the Code available before him.

\section{Risk of Loss}

In allocating the burden of risk of loss the Code draws a basic distinction between proper performance under the contract and improper performance or repudiation ("breach"), the bad actor being penalized with the risk of loss, tempered by insurance coverage as later pointed out.

In the situation where there is no question about seller or buyer not having lived up to his contractual obligation, the risk of loss in the cases involving shipment passes to the buyer on delivery to the carrier unless the contract requires the seller to deliver at destination. ${ }^{35}$ This differs little, if at all, from the result reached by the title approach under the Uniform Sales Act or under common law, except that the Code clarifies whether certain contracts are destination-contracts or mere shipmentcontracts. $^{30}$ In the sale of goods which are in the possession of some third party ("bailee") and of which the seller is not by the contract obliged to make further

\footnotetext{
${ }^{35}$ CODE $\$ 2-509$.

${ }^{30}$ See discussion about $\mathrm{C} \& \mathrm{~F}$ contracts, supra p. 15 .
} 
delivery, the inference in the Code is that the risk of loss passes to the buyer upon the seller's tender to the buyer of a negotiable document of title for the goods or, as the case may be, upon the seller's procurement of the bailee's acknowledgment (to the buyer?) of the buyer's right to possession; ${ }^{37}$ if the seller simply delivers and the buyer accepts a non-negotiable written direction to the bailee to deliver, risk of loss "remains on the seller until the buyer has had a reasonable time to present it."38 If the case does not involve the shipment or bailment above discussed, then the Code makes a sharp break with non-Code law; by the Code "the risk of loss passes to the buyer on his receipt of the goods if the seller is a merchant, otherwise the risk passes to the buyer on tender of delivery." ${ }^{30}$ So, if buyer $B$ calls up seller $S$ and says: "I'll take that power lawn-mower I was looking at this afternoon; I'll pick it up at your place in the morning," and $S$ says "Good, I'll hold it for you," then, if the chattel is destroyed by fire that night, whether loss falls on $S$ or on $B$ depends on whether $S$ is a "merchant." Me Merchant is defined in the Code as "a person who deals in goods of the kind or otherwise by his occupation holds himself out as having knowledge or skill peculiar to the practices or goods involved in the transaction" or who employs intermediaries holding themselves out as having such knowledge or skill, ${ }^{41}$ although by another Code section the provision affecting a merchant can be extended to non-merchants "when the circumstances and underlying reasons justify extending its application." ${ }^{42}$ This definition has provoked criticism. ${ }^{43}$ One wonders whether the definition was drafted more with an eye to the provisions relating to warranty obligations, ${ }^{44}$ receipt of written confirmation as affecting the Statute of Frauds, ${ }^{45}$ firm offers, ${ }^{46}$ written agreements to exclude oral modification, ${ }^{47}$ etc. In the risk of loss situation the Code idea is, roughly, that if the seller is a professional, and as such can be expected to be covered by insurance, let risk of loss be on him until the buyer gets possession. Although there seems to be enough merit in that idea to warrant the attempt to identify a risk-retaining seller, ${ }^{48}$

\footnotetext{
${ }^{37}$ CODE $\$ 2-503(4)$. This inference would seem justified not only by traditional law but also by the express provision for delayed passing of risk of loss to the buyer in the case of a mere delivery order-sec text to note 38 , infra.

${ }^{38}$ COnE $\$ 2-503(4)$. This would change such questionable decisions under the Uniform Sales Act as Cundill v. Lewis, 245 N. Y. 383,157 N. E. 502 (1927), where the buyer, for no explained reason, delayed presenting the delivery order for some two weeks, yet risk of loss (theft from the warchouse) was put on the seller.

${ }^{30}$ Cone \$2-509(2). "Tender of delivery" is a term of art, under the Code; see \$2-503(1).

${ }^{40}$ Before concluding that this is drastic, it would be interesting to see whether under the traditional title-passing approach courts have "found" title to pass sooner where the seller is a professional (a business enterprise) than where the seller is a casual seller, in the risk of loss cases.

${ }^{4}$ CoDE $\$ 2-104(1)$ as modified by the September 1950, Revisions.

43 CODE $\$ \mathrm{I}-\mathrm{I} 02$.

${ }^{13}$ Waite, The Proposed Nesv Uniform Sales Act, 48 Mrch. L. Rev. 603, 617-6r9 (1950); Rabcl, The Sales Law in the Proposed Commercial Code, I7 U. of CHI. L. Rev. 427, 431-432 (1950). See also Williston, The Law of Sales in the Proposed Uniform Commercial Code, 63 Harv. L. Rev. 561, 572 (1950).

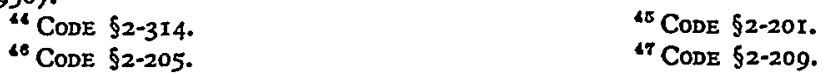

${ }^{8}$ There is nothing new in the idea that insurance carriage can affect liability, even in minds loftier than those of juries. In Tennessee and Colorado the rule seems to be that a charitable institution can be
} 
the Code's present definition seems to be less a provision of precision than an invitation to courts to use their common sense in detecting a professional. ${ }^{49}$ At any rate, even with such ambiguous sellers as farmers, ${ }^{50}$ query whether the proposed definition of merchant will increase litigation. At present, suppose that farmer $S$ contracts to sell at $\$$ ro per ton his entire present stack of hay to $B$, excepting 30 tons which are to be kept out for $S, B$ to take the hay right there where it is, the stack to be measured next Monday; before Monday the hay is destroyed by fire, without fault; $S$ has several witnesses who can testify that they knew the amount of hay in the stack, say, 200 tons. Does the loss of 200 tons or of only 30 tons fall on $S$ ? (Let us agree that the law is that if measuring is to take place merely to ascertain the price, that fact does not alter any title-passing presumption otherwise arising, although even that is by no means clear, either under the Uniform Sales Act or at common law.) Is measuring off the 30 tons to be retained by $S$ a "condition precedent" to the passing of title, in the light of the presumed intention of the parties? ${ }^{51}$ Even if the ascertainment of the intention is a question "of law" for the court (as where the contract is in writing), it will take a litigation at present to tell us what the law is. ${ }^{52}$

With respect to the effect of failure to live up to the contract on allocation of risk of loss, one phase of the Code substantially reaffirms existing law, viz., that where

liable for torts if it carries instrance. O'Connor v. Boulder Colorado Sanitarium, ro5 Colo. 259, 96 P.2d 835 (1939); Vanderbilt University v. Henderson, 23 Tenn. App. 135, 127 S. W. $2 d 284$ (1938). See approval of the liable-if-insured doctrine in the later case of Baptist Memorial Hospital v. Couillens, I76 Tenn. 300, 140 S. W. 2d 1088, 1092 (1940).

${ }^{40}$ As an alternative to the Code treatment, how about providing that pre-delivery risk of loss remains with 3 "seller who is a professional producer or dealer with respect to those goods or is one who carries or can be expected to carry insurance"? A number of cases litigated in recent years (but not involving risk of loss problems) have involved sales of this sort: a railroad selling scrap, an enterprise selling a part of its equipment or one item [e.g., a ship] or selling out its stock in trade. Query: "merchants"?

${ }^{80}$ A farmer would seem to fit the definition of "merchant," at least when he is selling his cash crops, but the Comment to Code \$2-509 observes that farmers generally fall within the category of "occasional" sellers, "although under some circumstances they will be classified as merchants as to specific goods and for specific purposes." In view of the somewhat authoritative force of the official Comments under the Code, a court might here see an invitation to take a non-merchant view of farmers. Perhaps the Code Comment should have been phrased the other way around: while a farmer may be a casual seller with respect to some of his sales, he is to be viewed as a merchant with respect to sales of his customary cash crops. A check in the Fifth Decennial Digest of the title-issue decisions involving farmers (most of them not involving risk of loss problem) shows sales of this sort: several hundred turkeys by a Minnesota turkey farmer, several hundred head of cattle by a Nerv Mexico rancher, entire citrus crops by owners of California or Florida orchards, daily pick-up of milk by dairy company from farmer producers, sale of olive crop by California olive grower, sale of 2,400 sack grain crop. As against these, there is an occasional case like that of the Alabama farmer who paid for his car repairs by "selling" to the repairman his mare and farming tools.

But perhaps the Code draftsmen, wanting to get as wide adoption as possible of the Code, had one eye on farmer-sensitive legislatures.

${ }^{51}$ In Cassinelli v. Humphrey Supply Co., 43 Nev. 208, I83 Pac. 523 (19I9), under the Uniform Sales Act, title was "found" not to have passed under similar circumstances. Cf. Radloff v. Bragmus, 2I4 Minn. I30, 7 N. W. $2 \mathrm{~d} 49 \mathrm{I}$ (I943), where title to a flock of turkeys was "found" to have passed at the time of the bargain, despite the fact that no grading had yet occurred to distinguish the No. 2's which were to bring $3 \phi$ a pound less; result, the disaster of the Minnesota blizzard of November Ir, I940, fell on the buyer.

${ }^{22}$ E.g., consider the Cassinelli case together with the turkey case, supra note 5I. Incidentally, it would seem that under the Code the loss in that case would have fallen on the seller, as a "merchant." See supra note 50. 
seller's tender or delivery fails to conform to the contract, the risk of loss remains on the seller ${ }^{53}$ (until the failure is cured or the buyer accepts). That simply restates the result traditionally reached, through title, by finding that title was not intended to pass until the seller himself had properly performed. ${ }^{54}$ But the Code presents novel applications of the idea that default is to be penalized by risk-bearing, through provisions the effect of which is substantially as follows: when one party as a result of default by the other finds himself with unwanted goods on hand which the other ought to take, the aggrieved party may treat the risk of loss as falling on the other "to the extent of any deficiency in his [the aggrieved party's] effective insurance coverage, ${ }^{\prime \prime 55}$ unless a fuller risk of loss is already on the defaulter under some other provision of the Code. The aggrieved party might be a rightfully rescinding ${ }^{60}$ buyer with the goods still on his hands ${ }^{57}$ or a seller faced with buyer's repudiation after identification of conforming goods but before delivery. The Uniform Sales Act had made some attempt to saddle the defaulter with risk of loss but the attempt only went to default in delaying delivery, and the attempt raised embarrassing proximate cause difficulties by its reference to "loss which might not have occurred but for such fault." N8 Neither the Uniform Sales Act nor the common law geared the loss, shifted or unshifted, to the aggrieved possessor's insurance coverage. It remains to be seen whether sharp drafters of insurance policies will try to work out clauses to make the insurance non-effective under these Code provisions.

\section{Seller's Price Recovery}

Under the Code the seller is entitled to the purchase price in three situations: (I) where the buyer has accepted the goods, (2) where the goods are lost or damaged after risk of loss has passed to the buyer, irrespective of his acceptance, and (3) where seller's resale is impracticable. ${ }^{59}$

The first above situation parallels, more or less loosely, the non-Code law entitling the seller to the price if title has passed. In abandoning "title" in favor of "acceptance," the Code no doubt hopes to make available a more tangible criterion. Whether judicial decisions will justify this hope remains to be seen. Since by "acceptance" is meant that the buyer "takes particular goods which have been appropriated to the contract as his own" ${ }^{10}$ and since acceptance is said always to include "acceptance of

${ }^{83}$ CODE \$2-510(I).

"5 Subject to the vicissitudes of title finding-recall the non-risk cases supra, notes $26,30,31,33$.

${ }^{55}$ CoDE $\$ 2-510(2)$ and (3).

"To The Code avoids the term "rescission," "rescinding," and the like; instead it speaks of a buyer who "revokes his acceptance," and of pertinent narrow operative facts and their legal consequences.

${ }^{57}$ At common law the risk of loss after the buyer gives notice of rightful rescission would seem to be on the seller, in consequence of revesting of title in the seller. See Doane v. Dunham, 79 Ill. $13 \mathrm{I}$ (1875). Likewise under the UNIFORM SALES Acr, $\$ 69(4)$ and (5).

${ }_{68}$ UNIFORM SAIES Acr $\$ 22(b)$. For a good risk of loss case presenting facts which invite an entirely different analysis of risk of loss under the Code from that under the Uniform Sales Act or common law, see Rylance v. James Walker Co., I29 Md. 475, 99 Atl. 597 (Ig16) (under Uniform Sales Act).

${ }^{80}$ CODE $\$ 2-709$.

${ }^{\text {eo }}$ That is the meaning ascribed to "acceptance" in official Comment to $\$ 2.606$; the tcrm is not defined in the text of the Code. 
title," on the already-existing problem of what constitutes acceptance under the Uniform Sales Act, as well as at common law, indicate that an acceptance controversy is much more likely to relate to tangible overt acts than is pursuit of title. ${ }^{62}$

In the second above-mentioned situation allowing price recovery, price recovery is tied to risk of loss if loss has in fact occurred. Even outside the Code, that tie-up is a traditional one, through the familiar common denominator of title. But under the Code, when loss has not occurred, one must be careful not to generalize that the seller is entitled to the purchase price whenever risk of loss has passed to the buyere.g., sale of goods (not falling in the third category) where for some Code reason risk has passed to the buyer.

In the third category of price recovery are "goods identified to the contract if the seller is unable after reasonable effort to resell them at a reasonable price or the circumstances reasonably indicate that such effort will be unavailing." 63 The accompanying official Comment indicates that it was meant to select a more objective test than the corresponding words of the Uniform Sales Act, viz., "if they (the goods) cannot readily be resold for a reasonable price." ${ }^{\text {"4t }}$ The problem has always been with us, with differing choices of policy and niceties of language. Writers have frequently commented upon the superiority of this or that view, ranging from remitting the seller in all cases to an action for damages (subject to permitting price action at least after delivery and acceptance of conforming goods), ${ }^{65}$ through allowing price action for non-marketable goods, ${ }^{66}$ to allowing price action almost as a matter of course upon tender of delivery despite buyer's ante-tender repudiation. Judicial or legislative authority can be found for each view. I believe that the Code, like the Uniform Sales Act, wisely chose a middle ground" reasonable effort to resell them at a reasonable price or the circumstances reasonably indicate that such effort will be unavailing." Within the policy so chosen there remains the question: What is the best criterion of the impracticability of remitting the seller to the remedy of damages or of resale-plus-damages? Despite its attempt to be more objective in the standard chosen than was the Uniform Sales Act, the Code's criterion bristles with that weasel-word "reasonable" and "reasonably." Per-

o1 Official Comment to Code, $\$ 2-606$.

os See annotations in I-A U. L. A., SALES (1950) to $\$ 48$ of Uniform Sales Act, on "what constitutes acceptance."

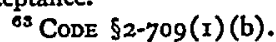

- UNIFORM SALES ACT $\$ 6_{3}(3)$, allowing price recovery even if title has not passed.

ov Such view has usually been couched in terms of "title"; if such attitude were to be adopted in the Code, not "title-passing" would have to be chosen but, rather, acceptance or actual receipt.

${ }^{\circ}$ Whatever be the language to approximate this thought, such as "not readily resalable for a reasonable price," "specially made" for the buyer's unique requirements, etc. "

${ }^{\circ 7}$ If one had to choose between extremes, I find it hard to favor the Civilian and former New York view which concedes the purchase price almost as a matter of course. While we need waste no sympathy on welching buyers, it would seem to be the rare case where the aggrieved seller is not in a better position to sound out the best outlets for the rejected goods-frequently even of specially made goods. On the other hand, if a price action lends itself more readily to summary procedure than does a damage action, there is much to be said for readier allowance to an aggrieved seller of the quicker action. 
haps there is no way to avoid the delicate balancing act always connected with the word "reasonable"; it has been suggested, however, that a still more objective test would be to give the seller a right to the purchase price if the goods have "no current price." 88

Although in the impracticable resale situation it is only with respect to goods "identified to the contract" that the seller has his purchase price action under the Code, it must be observed that the Code gives an aggrieved seller faced with a repudiating buyer the right to "identify" to the contract conforming goods on hand even after an attempted repudiation. ${ }^{69}$ Presumably in the usual forced-sale case, i.e., where specially made goods are the subject matter of the contract, the "identification" will frequently have occurred by making a start on the goods before the attempted cancellation; the qualified right then to go on to earn the purchase price under the Code is comparable to that under the Uniform Sales Act. ${ }^{70}$

The Uniform Sales Act allows a seller a price action simply by the calendar where under the terms of the contract "the price is payable on a day certain,"71 irrespective of title-passing or other price-allowance factors. That appointed-day provision is either an awkward rationalization of an abundantly justified price action in conditional sales where the possessing buyer defaults before final payment, or is an unquestioning adherence to some abstract notion of contracted independency of conditions. Price recovery on such appointed-day grounds is denied under the Code; apparently the Code's enumeration of cases where price action is permitted is intended to be exhaustive. ${ }^{72}$

That still leaves the question, however, whether under the Code the seller can maintain an action for the price simply on the strength of a no-cancellation clause or similar clauses, usually boiler plate in sellers' standard prefabricated contract forms. At their extreme, the sellers' clauses run to this effect: on any attempt by the buyer to repudiate the agreement, the contract price of the goods becomes due and payable, irrespective of lack of prior delivery or appropriation of the goods. There is authority that such clauses support a price action, on the flat reasoning that by the contract the purchase price "became payable" upon the buyer's repudiation; sometimes the above-mentioned $\$ \sigma_{3}(2)$ of the Uniform Sales Act is judicially cited as squarely covering the case ("payable on a day certain"-and the day of buyer's repudiation is that day); sometimes that section is judicially cited to show that the

\footnotetext{
'Rabel, The Sales Law in the Proposed Code, I7 U. of Crr. L. Rev. 427, 440 (1950). The suggestion stems from the draft of a once projected international sales statute, as to which sce gencrally Rabel, A Draft of an International Law of Sales, 5 U. of CH. L. Rev. 543 (1938).

${ }^{\circ}$ CODE $\$ \$ 2-704,2-703$. "Identification" under the Code would be quite comparable to "appropriation" in non-code sales law (see Code \$2-50r) if it were possible to disassociate "appropriation" from title-passing.

${ }^{70}$ Compare CODE $\$ 2-704$, with UNIFORM SALES Acr $\$ 64(4)$. For discussion under the Act and common law, see 3 Williston, SaIES $\$ 589$ (Perm. ed. I948).

${ }^{21}$ UNIFORM SALES ACT $\$ 6_{3}(2)$.

72 Official Comment to Code, \$2-709.
} 
legislature could not have intended to invalidate a price-due-on-default agreement. ${ }^{73}$ Equally available, for a contrary conclusion, is the technical argument that the buyer's promise to pay is, after all, only a promise, for breach of which he is to pay damages, ${ }^{74}$ with the corollary that there are limits to damage-fixing agreements.

It is not clear under the Code how effective the sellers' right-to-price clauses would be. On the one hand, an official Comment states that the Code section governing price actions "is exhaustive in its enumeration of cases where an action for the price lies"; ${ }^{75}$ on the other hand, the text of the Code itself has a provision that the parties may themselves by their contract "provide for remedies in addition to or in substitution for those provided in this Article."76 Query what is the effect of still another Code section to the effect that damages may be liquidated in the contract but only in an amount which is reasonable in the light of the anticipated or actual harm caused by the breach; ${ }^{\mathbf{7 7}}$ arguably a strong-arm price clause is in the nature of a penalty. Query, too, what bearing has the "unconscionable contract" provision of the Code, inviting courts to disregard "unconscionable" clauses. ${ }^{78}$

\section{Rights in the Goods Upon Other's Insolvency}

Intimation has already been given in these pages of the judicial tendency to manipulate title into "having passed" where the buyer has paid all or a substantial portion of the price before delivery. Other judicial techniques have also developed, here and there, to protect the prepaying buyer. Thus, some courts have viewed the seller's insolvency as a ground for granting specific performance to the prepaying buyer, with varying degrees of concern or unconcern over the possible resulting inequality to the seller's other "creditors."79 Some courts have given a buyer an "equitable lien" on the goods in the seller's possession when the buyer's prepayment of the price (or part of the price) had been made to finance the seller's production of those goods, even though this might give the buyer a priority in these assets of the insolvent seller as against other creditors. ${ }^{80}$ And earlier drafts of the Code contained a similar "enabling lien" provision on identified goods in favor of a financing

${ }^{73}$ National Cash Register Co. v. Lyon, 257 App. Div. 273, I3 N. Y. S.2d I (rst Dep't I939); L. Grauman Soda Fountain Co., Inc. v. Etter, 31 Ariz. I5I, I6 P.2d 417 (1932). The facts in the National Cash Register case, in particular, lead to doubts about the wisdom of upholding strong-arm price clauses; there the buyer repudiated the deal very shortly after making the contract and before any tender of delivery, because he learned that his place of business was to be taken in condemnation proceedings and accordingly he no longer needed a cash register.

7 Knight \& Bostwick v. Moore, 203 Wis. 540, 234 N. W. 902 (193 I), in which case the court gave the silent treatment to Renne v. Volk, 188 Wis. 505,205 N. W. 385 (I925) which had taken a different attitude.

${ }^{75}$ Comment to Code, $\$ 2-709$.

26 CODE $\$ 2-721$.

"CODE $\$ 2-720$.

${ }^{28}$ CODE \$2-302. This section takes an important step in closing the cultural lag between lego-political theory of the role of contract and the ihflexibility of mass transactions conducted through limitedly authorized personnel in the hierarchies of commercial enterprise.

10 Horack, Insolvency and Specific Performance, 3 I Harv. L. Riev. 702 (1918).

${ }^{80}$ Hurley v. A. T. \& S. F. Ry., 213 U. S. 126 (Ig08); Grief Bros. Cooperage Co. v. Mullinix, 264 Fed. 39 r (8th Cir. I920). If the seller is in bankruptey this would raise the question of the validity under the present Bankruptcy Act of such an "equitable lien." 
buyer, though limited to one season or to a particular production operation. ${ }^{81}$ (Presumably the policy against secret liens led to abandonment of such a provision in the current draft of the Code.) The foregoing indicates that the urge to do something for the prepaying buyer upon the seller's insolvency has expressed itself in one way or another, however clumsily. The Code, then, gives but a new twist to an old idea in providing that a prepaying buyer can recover the goods themselves, once identified, even though they have never left the seller's control (and, of course, irrespective of "title"), if the seller becomes insolvent within ro days after receipt of the first installment on their price. ${ }^{82}$

When it came to the situation of the unpaid seller who had already made delivery of the goods, it was more difficult at common law or under the Uniform Sales Act to achieve a judicial manipulation of title so as to protect the seller on the buyer's insolvency by finding that title had not passed. (Even here some room for play existed within the concept of "cash sale".) What with specification, appropriation, and downright delivery, even the flexibility of title offered little help to the seller. ${ }^{83}$ Perhaps he merited none; at least if considerable time had elapsed since delivery of the goods, he could be viewed as a credit extender, like any other general creditor. Even so, if the buyer went into bankruptcy soon after procuring the goods on credit, courts came to the aid of the reclaiming seller by an ingenious "finding" that a buyer in his financial position could not at the time of the purchase, have had an intention to pay, hence the sale was rescindable for fraud. ${ }^{8 *}$ The Code handles the situation of the unpaid seller who after delivery discovers the buyer to be insolvent by allowing the seller within Io days after receipt of the goods to reclaim any goods received by the buyer on credit. ${ }^{85}$ One notes the similarity in treatment to the case of the prepaying buyer faced with an insolvent seller.

\section{Seller's Resale, Damages, and Interplay of Title}

At common law and to a considerable degree under the Uniform Sales Act, the location of title as between seller and buyer had a number of other consequences relating to the seller's remedies, besides affecting his right to a purchase price action.

For one thing, in a buyer's suit for damages for seller's failure to ship the goods, courts have inclined to talk about title, relating the title-passing place and time to the place and time for delivery and hence to the place and time for determining the market price. This, in turn, entered into the measure of damages, viz., market price

${ }^{81}$ May 1949 Draft, $\$ 2-402 ;$ April 1944 Draft, $\$ 55$.

82 CODE $\$ 2-502(1)$. See also supra, note 28 .

${ }^{83}$ Even so, the flexibility of title-passing was helpful to the farmers in the grain elevator "deposits" faced with a bankrupt or otherwise insolvent elevatorman. The baffing legal confusion and refinements regarding title-passing that grew out of grain elevator cases is familiar knowledge. If one were forced to make a generalization about title-passing in this field, especially in the days before legislation in important grain states regulated insurance coverage and financial stability, one might say: if the elevator burned down, title had passed; if the elevatorman went into bankruptcy, title had not passed.

${ }^{84}$ California Conserving Co. v. D'Avanzo, 62 F.2d 528 (2d Cir. I933), opinion by L. Hand.

${ }^{85}$ CODE $\$ 2-702(\mathrm{I})(\mathrm{b})$. Written misrepresentation of solvency made by the buyer within three months removes the ro day limitation. 
minus contract price. So, in a contract looking to shipment from San Francisco to New York, F.O.B. San Francisco, cash against documents, the buyer's damages for the seller's failure to ship were held measurable by San Francisco prices; ${ }^{86}$ at that place, said the court, title and risk would have passed, hence that place measures the damages. What of a buyer who does not learn of such breach by the seller until about the time the goods ought to have arrived? Obviously a more refined tool for working out damages is needed than title. (Indeed, a careful reading of the case just discussed will reveal the court's recognition of this.) Here again the Code has a non-title approach to a buyer's damages: (I) if the buyer "covers" in good faith by any reasonable purchase, the price which he has to pay measures damages; ${ }^{87}$ (2) for seller's non-delivery, the price current at the time when the buyer learns of the breach and does not cover is what counts; ${ }^{88}$ (3) the place for determining the price is the place for tender or, in cases of rejection after arrival or revocation of acceptance, the place of arrival..$^{89}$

Title has frequently played a similarly significant role in the seller's resale situation. Take the case where the buyer wrongfully refuses to take delivery, the seller resells at a price below the contract price and now sues for damages, asking the difference between the contract price and resale price. If title to the goods had already passed to the buyer, it is fairly clear both at common law and under the Uniform Sales Act that a resale made with reasonable care and judgment fixed the damages. Two points are to be noted: (I) the resale did not have to be made at "the nearest available market" to the agreed place of delivery (which normally would be that place)-sale in some other market can still be commercially proper even if it appears in retrospect that some "nearer" available market might have brought a better price, and (2) the appropriate resale fixes the differential between contract price and resale price, instead of being merely evidence of the "value" of the goods. But if title had not passed, then this seller is said to be entitled to the difference between the contract price and the value or "market or current price"10 of the goods at the nearest available market to the place of delivery. There is also judicial language about "best obtainable price." Theoretically, even a reasonable merchant-like sale at the nearest available market does not fix for this litigation the value (or "the market or current price") of the goods; worse still is seller's position if he did not sell at nearest available market, ${ }^{91}$ or at some "best" market. So, the aggrieved seller (and much the same is true of an aggrieved buyer) may be forced to litigate a theoretical value in a theoretical market despite his actual, commercially decent resale.

Now, this unfortunate situation, where title has not passed, is by no means inevitable, either at common law or under the Uniform Sales Act. There are com-

${ }^{80}$ Standard Casing Co. v. California Casing Co., 233 N. Y. 413, I35 N. E. 834 (I922).

${ }^{87}$ CODE $\$ 2-712$.

${ }^{80}$ CODE $\$ 2-713(2)$.

${ }^{38}$ CODE $\$ 2-7 \times 3(\mathrm{I})$.

${ }^{\circ 0}$ UNIFORM SALES Act $\$ 64(3)$. While-the Act (same section) speaks merely of "an available market" and does not use the words "nearest available market," that still leaves an opening for common law stress on nearest market when several markets are available.

${ }^{\circ 1}$ See, e.g., Chapman v. Ingram, 30 Wis. 290 (I872). 
mon law decisions that permit a bona fide business-like resale to fix damages, ${ }^{02}$ or that by virtue of presumptions of various degrees of conclusiveness, just about let a seller's commercially decent resale fix the damages; one detects in the cases a strong inclination on the part of judges and juries to find that the resale was in fact made, or presumably made, in the best available or nearest available market. As for the Uniform Sales Act, one can hardly say that it did much to clarify the situation; in fact, perhaps, the contrary. Even assuming that $\$ 60$ of that Act fixes damages by the resale authorized by that section, it is by no means clear that $\$ 60$ applies to cases where title has not passed to the buyer; ${ }^{93}$ note that $\$ 60$ recognizes the right of resale by a "seller having a right of lien or having stopped the goods in transition," which suggests that $\$ 60$ relates to cases where title has passed. If $\$ 60$ applies only where title has passed to the buyer, the measure of damages in cases where title has not passed would seem to be governed by $\$ 64$, which merely lays down the general contract-price-minus-market-price rule, in absence of special circumstances. I shall not take the space to discuss whether $\S_{53}(\mathrm{I})$ and $\S_{53}(2)$, or even \$I, of the Uniform Sales Act could be beaten into meaning that $\$ 60$ applies even to resale under an executory sale $;^{94}$ suffice it to say that it is regrettable that only by tortuous reasoning can one manage to annihilate a distinction that should never have mattered enough to give rise to discussion, viz.: title-passed $v$. titlenot-passed. Whatever difference in view reasonable persons might entertain of the desirability of letting a good faith resale fix the damages, title location would seem irrelevant.

Fortunately, some decisions under the Uniform Sales Act, not scanning too meticulously the language of the Act, have taken the "fair and good faith" resale as fixing seller's damages even in executory sales. ${ }^{95}$

Under the Code, a seller's resale "made in good faith and with reasonable care and judgment" entitles the seller, in plain language, to "recover the difference between the resale price and the contract price," ${ }^{, 06}$ irrespective of passage of title. ${ }^{07}$

Correspondingly, of course, the Code does away with title-passing distinctions with reference to the notices of resale required from the seller to the buyer. In nonCode law, as a corollary to the distinction about title-passing with reference to the resale's fixing of damages, a resale where title had passed would require more

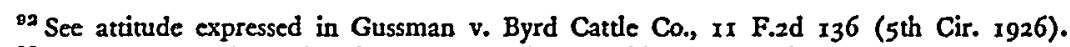

os To the effect that $\$ 60$ of that Act is inapplicable where title has not passed, sec L. Hand in Farrish Co. v. Madison Distributing Co., 37 F.2d 455 (2d Cir. 1930). However, resale in that case was recognized as fixing the damages because the goods were of a special kind for which there was no available market, hence contract price minus resale price was "the loss directly and naturally resulting" from the breach, under the language of $\$ 64(2)$.

"See Humphrey v. Sagouspe, 50 Nev. I57, 254 Pac. 1074 (1927).

${ }^{\text {os }}$ Obrecht v. Crawford, I75 Md. 385, I A.2d $\mathrm{I}$ (1938) is the outstanding case. It is disturbing to note that this excellent decision has been adversely criticized for violating the "nearest available market" rule, despite the fact the the seller had apparently done just what such a seller with such goods on hand would have done in the normal prudent operation of his business in the course of marketing; sec Note, 16 N.Y.U.L.Q. REv. 497 (I939).

${ }_{98}$ CODE $\$ 2-706(x)$.

${ }^{97}$ CODE \$2-703. 
notification to the buyer of seller's proposed action than resale under an executory sale, ${ }^{98}$ although the Uniform Sales Act has already just about abolished title distinctions on this score.99

\section{The Rescinding v. Rejecting Buyer of Non-Conforming Goods}

If the goods are not what the buyer had a right to get and he does not want to take or keep them, in familiar legal parlance he "rescinds" if title has passed to him, he "rejects" if title has not yet passed. Importance consequences have flowed from this distinction. Some of them have been minimized by the Uniform Sales Act, which gives the buyer the right not only to reject a tender of non-conforming goods but also to rescind upon his post-title-passing discovery of the defect. Others remain under, or are even created by, that Act. Thus, a rejecting buyer can recover damages for breach of the warranty, but a rescinding buyer runs into trouble if he seeks damages. He cannot both affirm and disaffirm, it is sometimes said, although legal commentators have frequently raised the question: why cannot the buyer rescind the passage of title and still stand on the underlying contract? The Uniform Sales Act has not helped, to say the least; by its language which apparently puts the buyer to a choice between rescission and other remedies. ${ }^{100}$ Ingenious courts, true, have managed to save the rescinding buyer's damage action by a number of evasive techniques, both at common law and under the Uniform Sales Act; ${ }^{101}$ and it is not surprising to see courts straining to find that title has not passed. ${ }^{102}$ But a mere glance at the annotations under $\$ 69(2)$ of the Uniform Sales Act shows the difficulty of predicting whether the court will find a way to give damages to the rescinding buyer. ${ }^{103}$ Fortunately, the buyer's rightful rejection upon inspection at destination in the shipment cases (even in cases of preinspection payment against documents) lends itself readily to a no-title-passed analysis, thus saving a large class of transactions from the dilemma.

Again, under the Uniform Sales Act, the rightfully rescinding buyer faced with a seller who refuses to refund the price and take the goods back has a lien, with all the lien-enforcing remedies of an unpaid seller, including right of sale. ${ }^{104}$ No comparable express provisions exist for the rejecting buyer. Fortunately, this does not

\footnotetext{
${ }^{28}$ See, e.g., Browne v. Giger, 221 Ala. 176, 128 So. 174 (1930).

"Uniforar Sales Act $\$ 60$ (2) and (4). Perhaps the Act went too far in dispensing with notice in all cases; compare Code, \$2-706(3) and (4)(b) \& (3).

${ }^{200}$ Uniform SAles ACT $\$ 69(2)$.

102 Rogge, Damages upon Rescission for Breach of Warranty, 28 Mrch. L. Rev. 26 (1929); Notes, 38 CoL. L. Rev. 888 (1938), 33 MrN. L. Rev. 406 (1949). Notable is the tour de force of conscripting $\$ 70$ of the Uniform Sales Act, a section which seemingly does no more than recognize damage rules like that of Hadley v. Baxendale $e t a l$, in order to give the rescinding buyer recovery of his special damages. See Russo v. Hochschild, 184 Md. 462, 4 I A.2d 600 (1945).

${ }^{102}$ In Tompkins v. J. \& R. Lamb, I2I App. Div. 366, ro6 N. Y. Supp. 6 (3d Dep't 1907), the buyer was only rejecting, said the court, and not rescinding, where he discovered that the granite was not "Westerly" months after the monument was set in his cemetery plot.

102 I-A U. L. A., SALES (1950) notes 34 p. 303, 39 p. 305, 42 p. 306.

${ }^{106}$ UnIfORM SALES ACT $\$ 69(5)$.
} 
seem to have handicapped the courts in giving the rejecting buyer the same resale remedy as the rescinding buyer. ${ }^{105}$

Again, the Uniform Sales Act requires the rescinding buyer to "return or offer to return" the goods, while it requires the rejecting buyer merely to notify the seller that he refuses to accept. ${ }^{106}$ Theoretically, this might seem to present pitfalls for buyers, although no great embarrassment seems actually to have arisen.

Naturally the Code, in minimizing title, seeks to abolish these distinctions between rescission and rejection. Indeed, it avoids the term "rescission," and speaks instead of "revocation of acceptance." A buyer who rightfully revokes his acceptance "has the same rights and duties with regard to the goods involved as if he had rejected them"; ${ }^{107}$ the rightful rejector and the rightful revoker of acceptance are specifically given the same remedies and the same security interest in the unwanted goods. ${ }^{108}$ The distinction between merely notifying the seller of rejection in some circumstances, as against holding the goods at seller's disposition in other circumstances, is made to turn on physical possession (not on title), with special provision for "merchant" buyers. ${ }^{109}$ But the significance of revocation of acceptance under the Code can only be appreciated by careful consideration of the Code sections dealing with what constitutes acceptance and the effect of acceptance, ${ }^{110}$ as well as of those relating to rejection and to remedies. Speaking of remedies, the Code might well make it clearer that a rescinding (acceptance-revoking) buyer who suffers special damages from the chattel's defectiveness can recover damages beyond those for nondelivery. ${ }^{111}$ True, by study of and cross-reference to a number of Code sections the careful student can finally land in the right place, but the process is nearly as arduous as making out a buyer's damages-plus-rescission right under the Uniform Sales Act.

\section{Purchasers and Creditors}

The "fraudulent" buyer, particularly the buyer who pays with a bad check, has given rise to much litigation, legalistic discussion, refinements, and, basically, divergent policy views. It is futile to seek a solution by definitions of "cash sale" or through the "true intent" of a seller who was mistaken, or through estoppel or through the "he who" rule (when one of two innocent persons must suffer, he who, etc.). ${ }^{112}$ There is a basic policy choice to be made where goods are sold by a seller to a buyer who gives a bad check and who resells to a bona fide purchaser, when a fight ensues over the goods between the latter and the original seller. One cannot

${ }^{105}$ Czarnikow-Rionda Co. v. West Market Grocery Co., 2I F.2d 309 (2d Cir. x927); Wilson \& Co. v. M. Werk Co., 104 Ohio St. 507, 136 N. E. 202 (1922). In the latter case the court blithely labelled the buyer's refusal to accept a non-conforming shipment a "rescission."

${ }^{100}$ UNIFORM SALES ACT $\$ \$ 69(5), 50$. ${ }^{207}$ CODE $\$ 2-608$.

${ }^{108}$ CODE $\$ 2-7 I 1$.

100 CODE $\$ \$ 2-602,2-603$.

${ }^{210}$ CODE $\$ \$ 2-606,2-607$. These Code sections relating to acceptance have been characterized as "bewildering" by a penetrating analyst. See Rabel, The Sales Law in the Proposed Commercial Code, 17 U. of ChI. L. REv. 427, 434-437 (1950).

111 See criticism of Code draftsmanship on this point by Waite, The Proposed New Uniform Sales Act, 48 Mich. L. REv. 603, 621-624 (1950).

${ }^{112}$ Sec Vold, Worthless Check Cash Sales, "Substantially Simultaneous," and Conflicting Analogies, I HAST. L. J. IXI (I950). 
Creditors' rights in goods that are the subject matter of sale are largely unaffected by the Code, except in one respect: "retention of possession in good faith and current course of trade by a merchant-seller for a commercially reasonable time after a sale or identification is not fraudulent."117 Otherwise, local rules relating to transfers "in fraud of" creditors still prevail, as is the case under the Uniform Sales Act.

\section{The Code's Title Section, Concluding Remarks}

Space forbids detailed discussion of the Code's title-passing section, \$2-40r. The foregoing discussion has suggested some reasons for its inclusion in an otherwise title-less endeavor, and has emphasized its relative unimportance, particularly in controversies between buyer and seller. Despite the importance of title in other areas of law and the law's seamless webness, no great embarrassment should arise from title de-emphasis. Under bankruptcy doctrines, for instance, to the effect that the trustee is vested with the title of the bankrupt (plus additional powers), it would seem that controversies over reclamation, risk, price, creditor-derived powers, etc. between the bankruptcy trustee and others are not made more difficult by the Code.

In conclusion it should be re-emphasized that the lawyer's analysis of his sales problems under the Code should not begin with a study of the title section, \$2-40I. One should stay away from that section as long as possible, first exploring all other sections that seem to bear any kinship to the specific issue involved; only when satisfied that nothing else in the Code is in point and that for some reason a title issue has to be faced, should one turn to \$2-40r. Else one will rise to the complacency of locating title in one person only to suffer the intellectual dénouement that risk, say, is on the other. For many of us that is going to mean a considerable change in attitude.

The Code looks like a more complicated mechanism, especially in the interrelationship of its parts, than the Uniform Sales Act, with reference to alleged title issues. But superficial simplicity is not to be confused with adequacy or smooth operation. The corporation law of the District of Columbia seems less complex than that of California-until you try to work under it. The early statutes of Minnesota, resorting to common law concept, simply stated that a deposit of grain in an elevator was a bailment. It didn't work; successive revisions of the grain elevator statutes became increasingly complex. This is a familiar phenomenon, frequently leading to the specialist. Even for the lawyer who is not a specialist, however, I suspect that he can find his way around in the Code satisfactorily with less time in its study than he would spend in locating title from the judicial decisions or in studying the refinements of cash sales and larcenous obtainers of possession.

${ }^{212}$ CODE \$2-402(I). 